with Cushing's Syndrome, Amer. J. Obstet. Gynec., 47, 43.

Liddle, G. W., EsteP, H. L., Kendall, J. W., WilliaM, W. C., and Townes, A. W. (1959): Clinical Application of a New Test of Pituitary Reserve, J. clin. Endocr., 19, 875.

LidDLE, G. W. (1960): Tests of Pituitary Adrenal Suppressibility in the Diagnosis of Cushing's Syndrome, J. clin. Endocr., 20, 1539.

LidDle, G. W., Bland, D. P., NeY, R. L., Nicholson, W. E., and SHIMIZU, N. (1962): Non-pituitary Neoplasm and Cushing's Syndrome. Ectopic Adrenocorticotrophin Produced by Non-pituitary Neoplasm, Arch. intern. Med., 111, 471.

LoCKWOOD, C. H. (1958): Studies of Adrenal Cortical Function in Three Cases of Carcinoma, Canad. med. Ass. J., 79, 728.

Mattingly, D. (1962): A Simple Fluorimetric Method for the Estimation of Free 11-Hydroxycorticoids in Human Plasma, J. clin. Path., 15, 374.

Mattingly, D., Dennin, P. M., Pearson, J., and COPE, C. L. (1964): Rapid Screening Test for Adrenocortical Function, Lancet, ii, 1046.

Parsons, V., and RIGBY, B. (1958): Cushing's Syndrome Associated with Adenocarcinoma of Ovary, Lancet, ii, 992.

Webster, G. D., Touchstone, J. C., and Suzuki, M. (1959): Adrenocortical Hyperplasia Occurring with Metastatic Carcinoma of the Prostate. Report of a Case Exhibiting Increased Urinary Aldersterone and Glucocorticoid Excretion, J. clin. Endocr., 19, 967.

Wilson, D. M., Power, M. H., and KePler, E. J. (1940): Alkalosis and Low Plasma Potassium in a Case of Cushing's Syndrome: Metabolic Study, J. clin. Invest., 19, 701.

\title{
MELIOIDOSIS IN A DIABETIC
}

\author{
G. L. Robinson, M.D. \\ M. BALLION, I.M.T.D. \\ Dreadnought Seamen's Hospital, Greenwich, London, S.E.10.
}

IN REPORTING a case which had reached hospital in England, Maegraith and Leithead (1964) mentioned the value to others of writing up this little-known disease when it is met. Burma and Malaya have been the main source of recently recorded cases (Peck and Zwanenberg, 1947; Paton, Peck and Van de Schaef, 1947; Harries, Lewis, Waring and Dowling, 1948; Green and Mankikar, 1949; Khaira, Young and Hart, 1959). The association of lung abscesses with the pyaemia in ours as well as other cases favours the sugestion of Khaira and others (1959) that the portal of entry may be respiratory; and, in the case of the officer serving in North Borneo described by Baird and Meers (1965), Whitmore's bacillus (Pseudomonas pseudomallei) was recovered from the sputum.

\section{Case Report}

Patient 036030 was a 52-year-old native of Goa, employed as a ship's pantryman, with a history of typhoid fever five years before, cystotomy for stone in the urinary bladder one year before, and diabetes for five years, for which he had ceased taking tablets one year before. He complained that his urine was red and that for two weeks he had had pain in the left loin, which had become swollen, hot and tender in the last three days. Temperature $102^{\circ} \mathrm{F}$, pulse 120 , BP $115 / 60 \mathrm{~mm}$. ${ }^{\mathrm{Hg}}$.; spleen just palpable; there were signs of subcutaneous abscess formation along the left tenth and eleventh ribs to the angle of the scapula. Pus was drained by incision two days after admission and chloramphenicol treatment begun. Another subcutaneous abscess appeared in the right groin, and was also incised. The temperature oscillated for the next few days in a near-normal range, then began to rise and remained above $101^{\circ} \mathrm{F}$ till the patient's death on the sixteenth day after admission.

Investigations. Urinary glucose on admission was $1 \%$ but no ketosis was found. Soluble insulin, 20 units b.d., was given when the fasting blood sugar was reported as $248 \mathrm{mg}$. $/ 100 \mathrm{ml}$. on the tenth day after admission. Blood findings were: ESR $46 \mathrm{~mm}$./ $\mathrm{hr}$., an absence of anaemia (PCV 44\%) and an initially low white cell level of $3,500 / \mathrm{cu}$. mm., which rose to 6,800 one week later and fell to 4,200 on the day of death. Complement fixation tests for syphilis and amoebiasis were negative. The urine contained pus and bile and grew Aerobacter. Serum bilirubin 3.5 $\mathrm{mg}$./ml., thymol turbidity 10 units, serum colloidal gold flocculation 221000 and serum alkaline phosphatase 27 K.A. units. Serum sodium $117 \mathrm{mEq} / 1$, total protein $6.4, \gamma$-globulin $2.6 \mathrm{~g}$. $/ 100 \mathrm{ml}$. The sputum yielded a heavy growth of Candida. The faeces contained a few ova of Trichuris. 'Agglutination tests with Salmonella, Proteus $\mathrm{OX}$ and Brucella were negative.

Bacteriology. The pus obtained on incising the subcutaneous abscess in the left loin, the blood culture taken two days before death and the pus obtained post-mortem from the left subdiaphragmatic abscess all gave a growth of Whitmore's bacillus. It was a motile, irregularly staining, gram-negative bacillus, with a tendency to form parallel bundles. It fermented glucose without gas, liquefied gelatin after three days, gave a soft olot in milk, reduced nitrate, formed a pellicle, grew on MacConkey's medium, showed very slight yellow pigmentation on nutrient agar, was not haemolytic on horse-blood agar and gave negative Voges-Proskauer, methyl red, indol, urea-splitting and citrate-utilization tests. The organism was agglutinated by the patient's serum diluted 1 in 60 but not by a control normal serum diluted 1 in 30 . A guinea-pig, intraperitoneally 
injected with $0.2 \mathrm{ml}$. of $24 \mathrm{hr}$. culture, was moribund after 24 hours: the testes were slightly swollen, gram-negative rods were demonstrated in the spleen and Whitmore's bacillus was cultivated from the blood. The laboratory of the London School of Hygiene and Tropical Medicine (by courtesy of Dr. Paul Chadwick) kindly confirmed the identification. The antibiotic sensitivities are recorded in the following table:-

Antibiotic incorporated in blood agar medium

Growth of Whitmore's bacillus aerobically after $24 \mathrm{hr}$. incubation at $37^{\circ}$

Pericillin 1 unit $/ \mathrm{ml}$.

+
+
0
+
+
+
+
+
+
+
+

Penicillin 10 units $/ \mathrm{ml}$.

Chlorampheniool $10 \mu \mathrm{g} . / \mathrm{ml}$.

Novobiocin $10 \mu \mathrm{g} . / \mathrm{ml}$.

Streptomycin $3 \mu \mathrm{g} . / \mathrm{ml}$.

Streptomycin $20 \mu \mathrm{g} . / \mathrm{ml}$.

Sulphathiazole $100 \mathrm{mg}$ \%

Vancomycin $10 \mu \mathrm{g} . / \mathrm{ml}$.

Oxytetracycline $2 \mu \mathrm{g} . / \mathrm{ml}$.

Oxytetracycline $20 \mu \mathrm{g} . / \mathrm{ml}$.

Erythromycin $2 \mu \mathrm{g} . / \mathrm{ml}$. ....

Erythromycin $10 \mu \mathrm{g} . / \mathrm{ml}$.

Neomycin $10 \mu \mathrm{g} . / \mathrm{ml}$.

Necropsy. The body was that of a rather thin Indian with greying hair, scars over shins, old surgical suprapubic scar, recent $2 \mathrm{~cm}$. incision below right Poupart's ligament, and other $2 \mathrm{~cm}$. long, in left loin over last rib. Beneath the latter was a healing subcutaneous abscess without deep connections, but overlying a haemorrhagic area in muscle. A similar haemorrhagic area was found in the fascia beneath the pectoral muscle near the right axilla. The region round the spleen showed many pockets of pus loculated by fibrous tissue. A few drachms of greenish pus were present at the splenic hilum and the neighbouring tail of pancreas showed some fibrosis. Adhesions to the splenic flexure of the colon and the greater curve of the stomach formed, with the left dome of the diaphragm, the boundaries of a burrowing type of abscess. Pus was recovered from behind the left suprarenal, from beside the coeliac axis and from an area just in front of and below the cardia. At the centre of this septic area, the enlarged spleen (685 g.) was converted into a tough walled sac containing semi-diffluent pink pulp. The splenic vein was clean and patent. No abscesses we seen in the enlarged fatty liver $(2,305$ g.). Fair numerous pyaemic abscesses, up to $1 \mathrm{~cm}$. diam., with haemorrhagic borders, were present in both kidneys (left 255 g., right 125 g.). The suprarenals we normal and there was no connection between the leff kidney and the abscess in the left hypochondriunc The abscess did not penetrate the left dome of the diaphragm, but organizing fibrinous exudate, wi a little turbid fluid, was present at the base of the left lung. 'Both lungs showed oedema and congestion and contained numerous small pyaemic abscesses. Am area $(2.5 \mathrm{~cm}$. diam.) of reactivated fibro-caseous tuberculosis was found at the left apex. An of fibrosed myocardial infarct was present in the posterior wall of the left ventricle of the heart (320 g.). Sectiof of the spleen showed simple perisplenic absces formation.

The case was under the care of $\mathrm{Mr}$. Stephen Powet M.S., and Dr. Ronald Hartley, M.R.C.P., to whom my thanks are due.

\section{REFERENCES}

BAIRD, J. P. and MeErs, P. D. (1965): Melioidosis $=$ Successful Treatment, Trans. roy. Soc. trop. Me Hyg., 59, 359.

GreEN, R. and Mankikar, D. S. (1949): Afebrite Cases of Medioidosis, Brit. med. J., i, 308.

Harries, E. J., Lewis, A. A. G., Waring, J. WOB., and Dowling, E. J. (1948): Meliodosis Tregted with Sulphonamides and Penicillin, Lancet, i, 363

Khaira, B. S., YounG, W. B. and HarT, P. de (1959): Melioidosis, Brit. med. J., i, 949.

MAegraith, B. G. and LeITHEAD, C. S. (1964\$2: Melioidosis: A Case Report, Lancet, i, 862.

PATON, J. P. J., PeCK, C. R., and VAN DE SChaAF, 冬 (1947): Report on a Case of Melioidosis from Siam, Brit. med. J., i, 336.

PeCK, C. R. and ZWanenburg, T. (1947): A Case of Melioidosis Presenting as an Abscess in the Neck, Brit. med. J., i, 337.

\title{
HAEMATOMA OF CHEST WALL DUE TO COUGHING
}

\author{
* H. P. GautaM, M.S., F.R.C.S., F.R.C.S.Ed., F.I.C.S. \\ Z. H. Ansari, M.B., B.S., D.C.H. \\ Thoracic Unit, East Birmingham Hospital.
}

FRACTURE of ribs (Jones, 1907; Palfrey, 1924; Watson-Jones, 1955) and tear in inferior (deep) epigastric vessels resulting in a haematoma of the abdominal wall (Bowles, 1939; Murray and Burger, 1954; Mackenzie and Macbeth, 1964; Rains and Capper, 1965; Stiles, Raskowski and Henry, 1965) have been described as the compli-

\footnotetext{
*Present address: Department of Cardio-Thoracic

Surgery, Hammersmith Hospital and Postgraduate

Medical School, London, W.12.
}

cations of violent coughing. Sudden muscuis strain has also been responsible for the subcabtaneous rupture of the rectus abdominis muse्ge (Illingworth and Dick, 1963). The development of haematoma of the chest wall due to coughifg has not yet been mentioned in the literature.

\section{Case Report}

D.C., aged 55 years, was admitted to E\$̊\$st Birmingham Hospital on 13th October, 1964 wigh cough and shortness of breath. For the past $f 4$ 